\title{
Nonstructural p26 proteins encoded by the 3'-proximal genes of velariviruses and criniviruses are orthologs
}

\author{
I. B. Rogozin ${ }^{1}$ A. A. Agranovsky 2,3 \\ Received: 30 September 2019 / Accepted: 5 November 2019 / Published online: 11 December 2019 \\ (c) The Author(s) 2019
}

\begin{abstract}
The 3'-most genes in RNA-2 of the Crinivirus genus members (family Closteroviridae) code for non-structural p26 proteins that share amino acid sequence similarity [Stewart LR, Hwang MS, Falk BW (2009) Virus Res 145:293-299]. In this study, sensitive bioinformatic tools have been used to identify the homologous p26 proteins encoded by the 3' genes in monopartite genomes of the members of Velarivirus, another Closteroviridae genus, and mint vein banding-associated virus, an unassigned member of the family. The p26 proteins showed similarity in their predicted secondary structures, but an amino acid sequence alignment showed no strictly conserved positions, thus indicating a high plasticity of these non-structural proteins. The implications of the sequence analysis for possible functions of the crinivirus and velarivirus p 26 proteins are discussed.
\end{abstract}

The family Closteroviridae includes about 50 filamentous plant viruses with large positive-sense RNA genomes that show numerous traces of recombination events, such as gene duplication and gene capture [1-3]. Closteroviruses contain up to 12 genes, most of which are arranged in two conserved modules: the replicative module, which encodes proteins responsible for RNA synthesis and membrane modification, and the five-gene block, which encodes proteins involved in particle formation and cell-to-cell movement [2-4] (Fig. 1). In addition, closteroviruses carry variable accessory genes in the 3' part of their genome (Fig. 1). Some products of the 3' genes are conserved in some members of the Closteroviridae $[3,5]$, whereas others have no apparent homologs and are species-specific.

Handling Editor: Jesús Navas-Castillo.

Electronic supplementary material The online version of this article (https://doi.org/10.1007/s00705-019-04491-8) contains supplementary material, which is available to authorized users.

A. A. Agranovsky

aaa@genebee.msu.su

1 National Center for Biotechnology Information, National Library of Medicine, National Institutes of Health, 8600 Rockville Pike, Bethesda, MD 20894, USA

2 Faculty of Biology, Moscow State University, Moscow 119991, Russia

3 Center of Bioengineering, Russian Academy of Sciences, Moscow, Russia
The members of the genus Crinivirus have bipartite genomes with RNA-1 and RNA-2 bearing the replicase module and the five-gene block, respectively, plus some additional 3' ORFs [6, 7] (Fig. 1). The 3' genes in RNA-2 of criniviruses code for proteins with a molecular weight of about $26 \mathrm{kDa}$ (p26) that have certain similarity in amino acid sequence and predicted secondary structure $[3,5]$ (Fig. 1). In this study, our purpose was to identify the p26-related proteins in members of the other genera and unassigned virus species of the family Closteroviridae.

The p26 protein sequences (Supplementary Table S1) were downloaded from the Refseq database using BLASTp and PSI-BLAST searches (www.ncbi.nlm.nih.gov) [8]. Multiple alignments were produced with the T-Coffee program [9]. HMMER2.0 toolbox [10] was used for Hidden Markov Model (HMM) reconstruction and sequence comparisons, HHpred [11] for HMM profile comparisons, and JPRED4 [12] for secondary structure predictions.

Initial BLAST and PSI-BLAST searches did not reveal any putative p26 protein homologs outside the genus Crinivirus when the crinivirus $\mathrm{p} 26$ sequences were used as a query (Supplementary Table S1). At the next step, we used HMMER 2.0, a sensitive tool for detecting remote protein homologs [10]. The hidden Markov model for the crinivirus p26 proteins was constructed and used for directed search for the 3' ORF products in members of other Closteroviridae genera (Velarivirus, Closterovirus, and Ampelovirus). Low probability values (indicating a statistically significant similarity) were obtained for the 27- to $29-\mathrm{kDa}$ proteins encoded 


\section{Crinivirus}
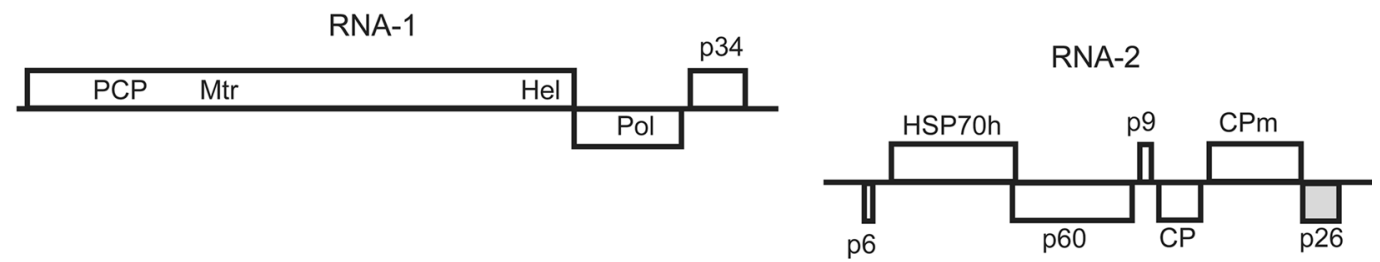

Velarivirus

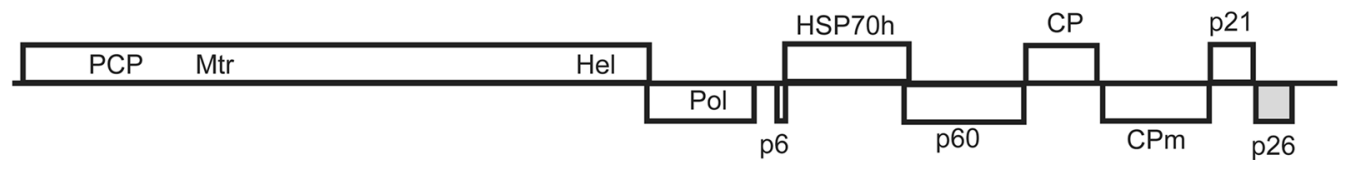

Fig. 1 Genome maps of representatives of the genera Crinivirus (lettuce infectious yellows virus, LIYV) and Velarivirus (little cherry virus $1, \mathrm{LChV}-1$ ) drawn approximately to scale. The arrow indicates the RNA 3' end. ORFs are shown as boxes. Encoded domains: PCP, papain-like cysteine proteinase; Mtr, methyltransferase; Hel, heli-

Table 1 Significance of similarities between the crinivirus p26 hidden Markov model and the velarivirus p26 proteins

\begin{tabular}{lll}
\hline Sequence ID & Score & E-value \\
\hline Cordyline virus 1 & -141.2 & 0.066 \\
ADU03662 & & \\
Cordyline virus 2 & -138.7 & 0.049 \\
AFJ05053 & & \\
Cordyline virus 3 AGF73886 & -126.8 & 0.012 \\
$\quad \begin{array}{l}\text { Cordyline virus 4 } \\
\text { AGF73893 }\end{array}$ & -136.9 & 0.04 \\
$\quad \begin{array}{l}\text { Grapevine leafroll-associated virus 7 } \\
\quad \text { AEQ59451 }\end{array}$ & -130.0 & 0.018 \\
Little cherry virus-1 CEO12417 & -125.1 & 0.0098 \\
\hline
\end{tabular}

by the 3'-most ORFs of velariviruses (below, also referred to as p26 proteins) (Table 1). Figure 2 shows a sequence alignment of the p26 proteins of criniviruses and velariviruses. Although some positions in the alignment are occupied by similar amino acid residues, none of them is strictly conserved (Fig. 2). Analysis of secondary structure suggests that the p 26 proteins of velariviruses and criniviruses are alpha-helical with a few beta-strands (Fig. 2), which corroborates the previous data for the crinivirus proteins [5]. Six alpha-helices in the $\mathrm{p} 26$ proteins have a similar location (Fig. 2), suggesting that these proteins share a common three-dimensional structure.

We also performed an additional HMM database search using the combined multiple alignment of crinivirus and velarivirus p26 proteins (Fig. 2) as a query for HMMER2.0. The 24-kDa protein of mint vein banding-associated virus $(\mathrm{MVBaV})$, an unassigned member of the family case; Pol, RNA polymerase. Proteins: p6, small hydrophobic protein; HSP70h, HSP70-related protein; p60, 60 kDa proteins; $\mathrm{CP}$ and $\mathrm{CPm}$, major and minor coat proteins, respectively. The ORFs for p26 proteins are shaded

Closteroviridae [13], was detected as a possible remote homolog (Fig. 3). A significant probability value (0.009) was obtained, supporting the relatedness of the MVBaV p24 to the p26 of criniviruses and velariviruses (Fig. 3). Attempts to include the $\mathrm{MVBaV}$ p24 into the multiple alignment using T-Coffee [9] were not successful due to the lack of detectable similarity in the C-terminal regions (Fig. 3). Additional HHPred database searches did not reveal any putative homologs of crinivirus/velarivirus p26 proteins among the available HMM profiles [11].

The data presented here indicate that the $\mathrm{p} 26$ genes are not Crinivirus taxon-specific as has been thought but are conserved across the monopartite genomes of Velarivirus members and mint vein banding-associated virus. Taking into account the 3 '-proximal location of the p26 genes

Fig. 2 Multiple alignment and predicted secondary structure of the p26 proteins of representatives of the genera Crinivirus and Velarivirus. Predicted alpha-helices $(\mathrm{H})$ and beta-strands $(\mathrm{B})$ are indicated. Criniviruses: PYVV (potato yellow vein virus, YP_054414.1), TVCV (tetterwort vein chlorosis virus, ALE18225.1), CYSDV (cucurbit yellow stunting disorder virus, NP_851578.1), bean yellow disorder virus (BnYDV, ABY66971.1), CCYV (cucurbit chlorotic yellows virus, YP_006522433.1), LCV (lettuce chlorosis virus, YP_003002364.1), BPYV (beet pseudo-yellows virus, AAQ97392.1), SPaV (strawberry pallidosis-associated virus, YP_025091.1), DVCV (diodia vein chlorosis virus, ADU25040.1), SPCSV (sweet potato chlorotic stunt virus, AEO37527.1), ToCV (tomato chlorosis virus, AJY78063.1), TICV (tomato infectious chlorosis virus, YP_003204962.1), LIYV (lettuce infectious yellows virus, NP_619699.1). Velariviruses: LChV-1 (little cherry virus 1, acc. CEO12417.1), GLRaV-7 (grapevine leafroll-associated virus 7, acc. AEQ59451.1), CoV-1 (cordyline virus 1, acc. ADU03662.1), CoV-2 (cordyline virus 2, AFJ05053.1), CoV-3 (cordyline virus 3, AGF73886.1), CoV-4 (cordyline virus 4, AGF73893.1) 


\section{Crinivirus}

Sec.structure

PVCV

TVCV

CYSDV

BNYDV

CCYV

$\mathrm{LCV}$

BPYV

SPaV

DVCV

SPCSV

TOCV

TICV

LIYV

\section{Velarivirus}

Sec.structure

LChV-1

GLRaV-7

CoV-1

$\mathrm{CoV}-2$

$\mathrm{COV}-3$

$\mathrm{COV}-4$

Sec.structure

PYVV

TVCV

CYSDV

BNYDV

CCYV

LCV

BPYV

SPaV

DVCV

SPCSV

ToCV

TICV

LIYV

Sec.structire LChV-1

GLRaV-7

CoV-1

$\mathrm{COV}-2$

$\mathrm{COV}-3$

CoV -4

Sec.structure

PYVV

TVCV

CYSDV

BnYDV

CCYV

LCV

BPYV

SPaV

DVCV

SPCSV

TOCV

TICV

LIYV

Sec.structure

LChV-1

GLRaV-7

CoV-1

CoV-2

CoV-3

CoV-4

HHHHHHHHHHHHHHH

HHHHHHHHHHHHHHHHHHHHHH

MENPELISY---------PS-N-GNTQFAS-DEFIAYQ-INAVVNALQKYA--LYSADELSAFR---DHCGVI-LNLISMME----YPIE------YARND-GGNNESL-INI I SHN-FNS IVNI IENY--CMYDVHVIDAAI---ETSHIL-INMCKMEF-----PTN-----DIEHI-QEDGEDF-PAI ISKN-LNSVLNAIQNH--SLYDMIMLDNAI---ETCYTL-IIMCQMEV---DYPIQ------EFELT-TDSGKSM-GELIAKN-FHTIVNVIQSH--QMFDIMNLEHVA---NLCYTL-HVMIDMSL------------------------NDVIAKN-FNTIVNI IQSH--ALFDKI HLENYR---ELCNVL-HVMINMSNMEVDYPIQ------GFEFG-GGGDKAM-AEVISKN-FNTIVNI IQNH--EMYDMI HLNHLH---ELCQVL-RVMINMRRM--DFPVL------TSETT-GEQ-AND-LDMLASN-VNI I LNILQDH--RQHDNFELQNAL---NSCSTV-INVCNMTSSFHDLTTS------DFQIS-NPV-QNE-RGI I SDN-INFI INIVENA--TSYTNAELEHAK---LCCOAL-LTFSNMTSNVFDLTLPSDDQVRDQDIS-RSS-TMT-NDRIASN-INQVLNVTNDF--KRYTVAELEHNL---LCCEAL-MTYAAMSGWD-DI PMQQN----YVSSS-VRNDDDI-AKICART-FNRAVNLLTDYS--QHTI PELRESR---FELGCI-RSLCEMEVVYNSDD---------VNSG-AGSGEDV-NTTVAKN-FYSITHVMSNYR--NYTPDEIKDAV---NVGYGL-LNLCEMDSPPRFVS---------VD-K-NE-ENDV-ILNFNSN-FWRVYSALSNDA--IMTWDELYMFK---QLCLSL-LTECEMNNFPEIFD--------DEST-CDYDKEIDHQELSDT-FWCLMDFISSKH--GKSVADINSGM---NTLINI-RKSLN-

MLN---TFGHE------GSSTN-K-RVDTF-ATQVSKKLLEFMHNVVTTLNGKNLS INELRGML---PQVLECKRFFEAMDLETRNDN-------- TM-F--R-ERD-------------------------------KCKIF-SCIIDMDKNCVANSTE------FTDTSDFENKKEI-NRVFSCI-VEAVDNIIDEI--CSLKVNNFNKLKNLSDHLRLI-EHFLKK MEDNSVVQTCD------GFDTSDLEDDRVR-NKLFSDM-MDEVDQIKSEI--CSSTTANSHKLKSMLKTLSLI-HHFLKK MDLESRSTE-------------KNRLK-NQILTSA-I DYFFNLKYYI--LKENAITLERKKNLLSKIRYL-YDFFKA MSSSYNNFD-------------MEQKR-NTMFTKI-FNCINDIESSI--LFNDSMTVSSLLQNISQLKTI-LSFVSK

BBBB

HHHH

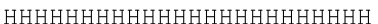

B RHGESVNMFSRNSK-I-F----ESLTNNSVPEETI LRNKGIYFPTLSVYELQDI---LNNFVVTLNFLIDV-KT-GIVTE TCSGEINLYSLNNK-R-V----ESLRQMNISVNQVVEEKHTLFPTLKGWQLEEI---IYQLIPVLSFLRSV-MT-CIMDD KLYEDVNLYSATNP-R-T----ESFRNASVNVNT I LNNKDKLFPKLSSWQIDDL---VKQLIPILNFLKDS-KT-KIMND NHEGYVNLYAENNP-R-V----DSFRDAGVKPEVLVNKKDKYFPTLTTWQLRDT---LSQLEPVLNFVTEL-KG-GLMND ENNNDINIYSENNR-T-L----GSFRDAGLDINNISARRNKLFPTLTPWQIRDV---LQQLESVLWFVTDL-KT-GLMDD DCTEDINLFSENNK-L-V----GSFRDAGLDMNNISSRRNKLFSTLTPRQLRDT---LDQLETVLNFLTDA-RF-GVMND LQTEDVNLFSTHSK-V-Y----QDLKSAGVSHEELSSQRSKYFSTLSTEDLKYL---MFDVANIFRLLLVA-RK-NLVDN ONNFKVSLFGKNSK-I-Y----NALRNS SHSDEEIERCKDYYFPTLRSFDVIDVIELMODFFAVLEFLINM-RK-GYFDF LNTFDVSLFSENSS-T-F----KVLRDSGHDEEEIKQNKQFYFPVLNDFDVKTI---MYDISKVLKFLIRY-KM-GYFEN NDDFNINLGADNNN-L-F----QGLNKLGVRADSLRVNSERFFPS ISSKVMTNV---IDSISSVMEFVIDL-NH-SGFST RLDRDVILVSPNSP-V-Y----NNYRDAGI PHNLLMENTARYFPVVNPSELGKI---LLGHISVLKFLEYF-TR-YGVDD SLPNNLILYHTNTM-P-H----EILGSRRINDTDIDLHSSRYFQNVTKQVVRFL---LEDYLI I INMKLHM-KK-GLLDV GSGKVVS ITDSYNK-TYF----HSQR-------GLTNVDSRINIDILKIDFISI---IDDLQI IFRGLIYK-DK-GFLDS

$\mathrm{HHHHH}$

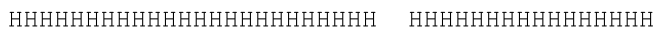
RRDETLETIGSRSK-M-F----SS-EVLEIDEDTVNEFKELFLMRIPIKLLIQY---CDDFILVFDILKNFLDK-TLINE KISSALNTLSSTSS-S-IVSKQQALSDISLSKDI LKKLGLFAAPVLTQGHTGFL---TESCGVPLEFLDEV-GR-DLLVS NENANVTFLDRKSREL-V----E--TYVTVNDKFILDNEQVMTTTMRMSEI IPK---VSELTKVLKLKKCI-LSGQVFSR NENLRVTY I DKRAKEL-I----E--RFIVLDERF I LNNEHVVTTTVKLADVLPM---VLELKGLCSLKIDF-SLRVVLTK NESSSVNYVNIEIKKL-F----E--TELHIEEESLIDSEEMFTSTVKISELGDO---LNELINILHLKODI -YTKRVLNN NEDITIKYVNADHKRL-V----S--SVIGDDDEFFLENETLIVDSVKSKDLVPN---IVELIKLLELKHRL-KTFSLLDS 


\begin{tabular}{|c|c|}
\hline Sec.structure & HHHHHHHHHHH \\
\hline PYVV & DDNGKQDIARFLKNMRTDDVDPK-KVLRKIVQDLNLAFMFELSFHYLN---DGL-I IFKIN-N-KH------- \\
\hline TVCV & VDNSDKLENLMLKQKIRKYLDK-NAREYLKEYITKNIMFELNFSFTC---FGI-NIKQIK-N-F------- \\
\hline CYSDV & DDSEKLEKLIKGYKSKRYLTK-SVRNELVNYFSNNLVYQISFLFDN---IGI-NIKPIK-N-F-- \\
\hline AYDV & IKDGKSVERMIKNFKKQKYLDE-NLRIKFKDF ISENLVYEINFEFKN---LGF-YLKPIK-NFN------ \\
\hline CYV & IRDDDCVDSVIKNFKRKKFLNE-KSRQKMKTLLANCLVYEITFNFGN---LGL-YMNPLK-N-F----- \\
\hline LCV & IKDGKTIDEVIKKYKKEKYLND-INRRKIKDLLSNHLVYEISFHFGG---LGL-PIKPLK-N-F------- \\
\hline BPYV & VADEYRFSHLLKSIKFPNKRSY-IKKGELIEICKESLIFKIS INYDH---LGL-NIKTIK-F-----D-- \\
\hline SPaV & LSDDFEVKNLIIKYKKFSKNNE-SKKLAMLKLLNESLIFKITFTFSH---VGL-EINSIS-S-PRQAF--. \\
\hline DVCV & VDNSYWLKTLLKKCANFSKTGE-EKRLILKTYINEHLKFKFAFRYNI---SSF-KI PEVS-N-----K---- \\
\hline PCSV & LFNDDILKI ISKAKKKIRPLSD-SERVLMAKS ITKGIHFEFHFTYRS---LGL-YLPKVT-N-SLTVCNKNR \\
\hline oCV & IRRKGYPNS-ENFNWFKNMISNYLYFDFVFRYSG---TRI-NIERIS-N-YYI---- \\
\hline TICV & IFEEDHRLKSLLKLFKKNKSLTS-KEIGVIRATINNGI I GKFTIK-RSFG-FGI-PFENIN----L----- \\
\hline LIYV & SPLDKQRKCSISSSHKKTNRLND-L--NNYITYLNDNIVLT--FRWKG---VGF-GGLSLN-D-IKI---- \\
\hline Sec.s & ВНHНHНHНHНHНHНHНHНHН \\
\hline LChV-1 & IVK-SECLKGFTTTLSSLFMYNK-GHRNSYARAITLNLKL----FIEH---SGL-LNGELAYNLV--VG-- \\
\hline GLRaV-7 & 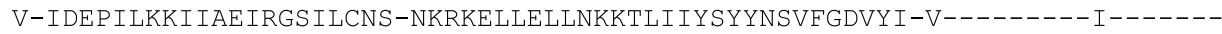 \\
\hline CoV-1 & RSDVLAYMKSVAK---GNSYFTF-LKHKPVDVEMNRNIIITL--L-------------E-------- \\
\hline-2 & 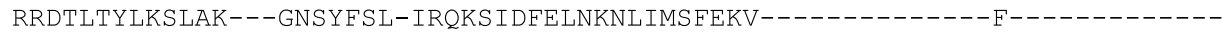 \\
\hline & JQSFSK---NLPSTIF-VRASSLLKDINSTMVISFDTTYKQ---L--- \\
\hline & 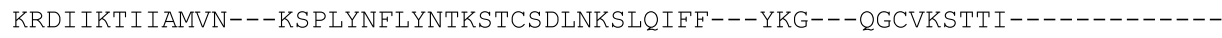 \\
\hline
\end{tabular}

Fig. 2 (continued)

Fig. 3 Sequence alignment between the hidden Markov model consensus sequence for the crinivirus and velarivirus p26 proteins and a remote homolog, mint vein bandingassociated virus 24-kDa protein (NC_038420.1). Due to the lack of detectable similarity in the C-terminal regions, only partial sequences are shown

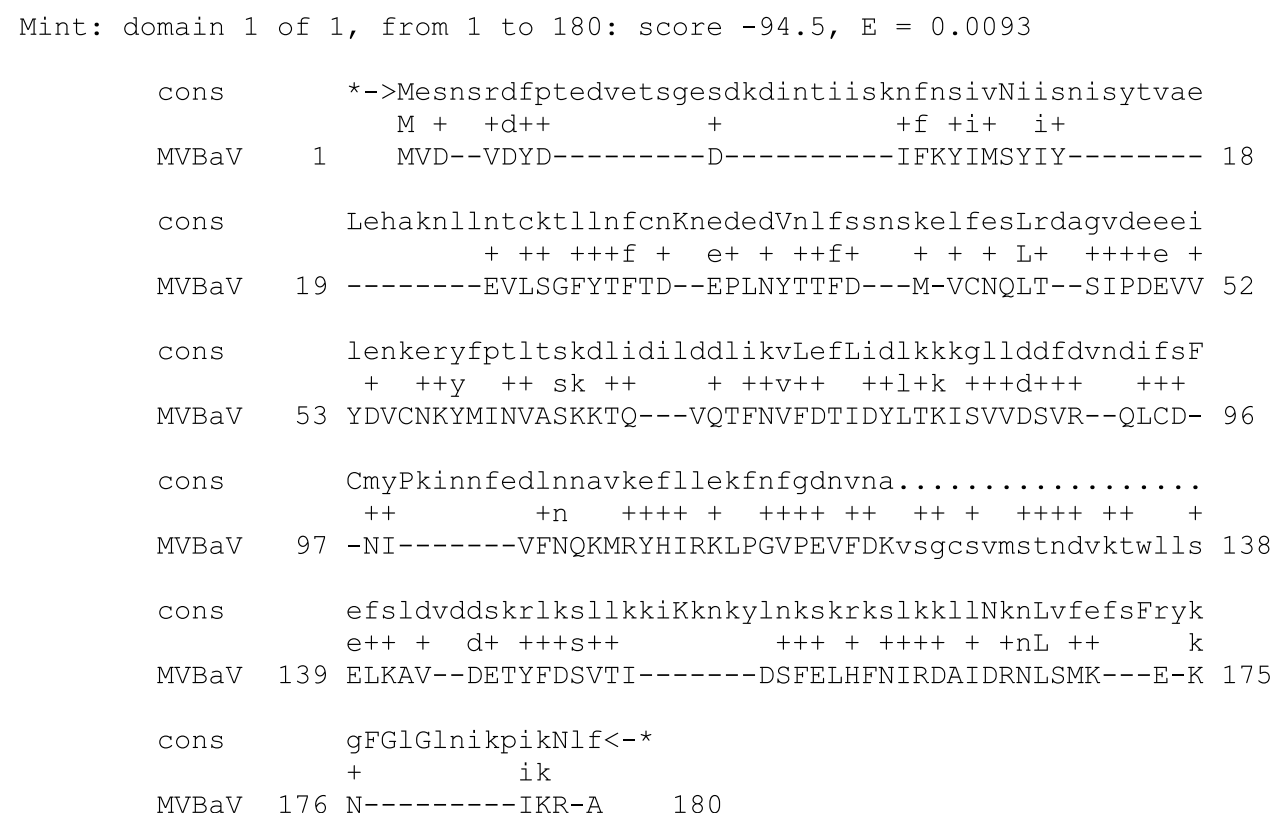

(Fig. 1), similarity of the predicted secondary structures, and statistically significant similarity of the amino acid sequences (Table 1, Fig. 2), it is likely that the p26 proteins of criniviruses and velariviruses are orthologs that may perform the same or similar function(s). It should be noted that members of the genera Crinivirus and Velarivirus are markedly different from each other in their biological properties and the genome structure. Criniviruses have divided genomes, are transmitted by whiteflies, and infect herbaceous hosts, whereas velariviruses possess monopartite genomes, have no known vectors, and infect woody hosts [2] (Fig. 1). The absence of conserved amino acid positions in the p26 alignment suggests high plasticity of these non-structural proteins, which may indicate their involvement in the response of virus systems to rapidly changing environmental conditions. On the other hand, the $\mathrm{p} 26$ protein of lettuce infectious yellows virus (LIYV), the type member of the genus Crinivirus, induces specific ultrastructures in the infected cells - conical plasmalemma deposits over plasmadesmata - that are thought to be associated with the vascular transport of the virus [7, 14, 15]. In support of this, a knockout LIYV p26 mutant proved to be unable to spread systemically in a Nicotiana benthamiana host [15]. Although the Closteroviridae members other than LIYV do not induce plasmalemma deposits, the involvement of 
crinivirus and velarivirus p26 proteins in systemic transport cannot be excluded and needs to be tested experimentally.

Acknowledgements We thank David Karlin for stimulating discussions on the p26 similarities, and Nik Gorgolyuk for critical reading of the manuscript. IBR was supported by the Intramural Research Program of the U.S. National Library of Medicine (Z01 ES065086) at the National Institutes of Health (US Department of Health and Human Services).

\section{Compliance with ethical standards}

Conflict of interest The authors declare that they have no conflict of interest.

Ethical approval This article does not contain any studies with human participants or animals performed by any of the authors.

Open Access This article is licensed under a Creative Commons Attribution 4.0 International License, which permits use, sharing, adaptation, distribution and reproduction in any medium or format, as long as you give appropriate credit to the original author(s) and the source, provide a link to the Creative Commons licence, and indicate if changes were made. The images or other third party material in this article are included in the article's Creative Commons licence, unless indicated otherwise in a credit line to the material. If material is not included in the article's Creative Commons licence and your intended use is not permitted by statutory regulation or exceeds the permitted use, you will need to obtain permission directly from the copyright holder. To view a copy of this licence, visit http://creativecommons.org/licenses/by/4.0/.

\section{References}

1. Agranovsky AA (1996) Principles of molecular organization, expression and evolution of closteroviruses: over the barriers. Adv Virus Res 47:119-158

2. Agranovsky A (2016) Closteroviruses: molecular biology, evolution and interactions with cells. In: Gaur RK, Petrov NM, Patil BL, Stoyanova MI (eds) Plant viruses: evolution and management. Springer, Singapore, pp 231-252. https://doi. org/10.1007/978-981-10-1406-2_14

3. Dolja VV, Kreuze JF, Valkonen JP (2006) Comparative and functional genomics of closteroviruses. Virus Res 117:38-51

4. Gushchin VA, Karlin DG, Makhotenko AV, Khromov AV, Erokhina TN, Solovyev AG, Morozov SY, Agranovsky AA (2017)
A conserved region in the Closterovirus 1a polyprotein drives extensive remodeling of endoplasmic reticulum membranes and induces motile globules in Nicotiana benthamiana cells. Virology 502:106-113

5. Stewart LR, Hwang MS, Falk BW (2009) Two Crinivirus-specific proteins of Lettuce infectious yellows virus (LIYV), P26 and P9, are self-interacting. Virus Res 145:293-299

6. Klaassen VA, Boeshore M, Koonin EV, Falk BW (1995) Genome structure and phylogenetic analysis of lettuce infectious yellows virus, a whitefly-transmitted, bipartite closterovirus. Virology 208:99-110

7. Kiss ZA, Medina V, Falk BW (2013) Crinivirus replication and host interactions. Front Microbiol 4:99. https://doi.org/10.3389/ fmicb.2013.00099

8. Altschul SF, Madden TL, Schaffer AA, Zhang J, Zhang Z, Miller W, Lipman DJ (1997) Gapped BLAST and PSI-BLAST: a new generation of protein database search programs. Nucleic Acids Res 25:3389-3402

9. Notredame C, Higgins DG, Heringa J (2000) T-Coffee: a novel method for fast and accurate multiple sequence alignment. J Mol Biol 302:205-217

10. Johnson LS, Eddy SR, Portugaly E (2010) Hidden Markov model speed heuristic and iterative HMM search procedure. BMC Bioinform 11:431

11. Söding J, Biegert A, Lupas AN (2005) The HHpred interactive server for protein homology detection and structure prediction. Nucleic Acids Res 33:W244-W248

12. Drozdetskiy A, Cole C, Procter J, Barton GJ (2015) JPred4: a protein secondary structure prediction server. Nucleic Acids Res 43:W389-W394

13. Tzanetakis IE, Postman JD, Martin RR (2005) A member of the Closteroviridae from mint with similarities to all three genera of the family. Plant Dis 89:654-658. https://doi.org/10.1094/ PD-89-0654

14. Qiao W, Medina V, Falk BW (2017) Inspirations on virus replication and cell-to-cell movement from studies examining the cytopathology induced by Lettuce infectious yellows virus in plant cells. Front Plant Sci 8:1672. https://doi.org/10.3389/fpls.2017.01672

15. Qiao W, Medina V, Kuo YW, Falk BW (2018) A distinct, nonvirion plant virus movement protein encoded by a crinivirus essential for systemic infection. MBio 9:e02230-18. https://doi. org/10.1128/mBio.02230-18

Publisher's Note Springer Nature remains neutral with regard to jurisdictional claims in published maps and institutional affiliations. 